\title{
Verification of Soil Test Crop Response Based Phosphorus Recommendation on Bread Wheat (Triticum Aestivum L.) in Yaya Gulele District of North Shewa Zone, Oromia
}

\author{
Dejene Getahun", Dereje Girma, Abreham Feyisa, Ajema Lemma, Lello Dejene \\ Oromia Agricultural Research Institute, Fitche Agricultural Research Center, Oromia, Ethiopia
}

Email address:

dejenegetahun2009@gmail.com (D. Getahun)

${ }^{*}$ Corresponding author

To cite this article:

Dejene Getahun, Dereje Girma, Abreham Feyisa, Ajema Lemma, Lello Dejene. Verification of Soil Test Crop Response Based Phosphorus Recommendation on Bread Wheat (Triticum Aestivum L.) in Yaya Gulele District of North Shewa Zone, Oromia. International Journal of Applied Agricultural Sciences.Vol. 6, No. 3, 2020, pp. 52-56. doi: 10.11648/j.ijaas.20200603.14

Received: April 27, 2020; Accepted: June 1, 2020; Published: June 15, 2020

\begin{abstract}
On farm verification trial of soil test based crop response phosphorus calibration study on bread Wheat was conducted at Yaya Gulele district of North Shewa zone during 2018 cropping season using optimum amount of nitrogen (92kgN/ha), critical P-value (23ppm) and Phosphorus requirement factor (3.7) determined during soil test based crop response phosphorus calibration study in the year 2017. Using the equation (23-pi) $\times 3.76$ which were developed during calibration study, verification trial was conducted on farmer's field of land unit $10 \mathrm{~m}$ by $10 \mathrm{~m}$ in the same districts with the objectives to verify research finding obtained from P-fertilizer Recommendation study on bread wheat crop and to provide site specific soil test based P-fertilizer recommendation. Soil test based P- calibration result (T3), Farmers' practice (T2) and the control (T1) were the treatments. The trial was laid out in RCBD considering farmers as replications. Analysis of Variance indicated that there was significant difference $(\mathrm{P}<0.05)$ for the treatments tested as fertilizer rates. The highest mean grain yield $(37.13 \mathrm{qt} / \mathrm{ha}) \mathrm{was}$ recorded with soil test based P -calibration result (STBPCR) which was significantly higher than farmer's practice $(21.98$ qt/ha) and followed by the control. MRR range from $857.27 \%$ in STBFR to $738.01 \%$ in farmer's practice. Agronomic data were collected on heading date, maturity date, plant height, and Stem length, and Spike length, biomass and grain yield. Therefore, it is concluded that for obtaining aimed yield target and profit with sustenance of soil fertility in Yaya Gulele Districts, the optimum rates for wheat Production were found to be $200 \mathrm{~kg} / \mathrm{ha}$ Urea $(92 \mathrm{~N} / \mathrm{ha})$ and Soil test based P-fertilizer recommendation could be followed for wheat Production.
\end{abstract}

Keywords: P-critical Value, P-requirement Factor, Calibration, Marginal Rate of Return

\section{Introduction}

Wheat is one of the most important crop plants in the world. It grows under a broad range of latitudes and altitudes; it is not only the most widely cultivated crop but also the most consumed food crop all over the world [11]. Wheat is one of the most important cereals cultivated in Ethiopia. Ethiopia is the largest producer of wheat in sub-Saharan Africa (SSA), over 1.8 million hectares annually [1]. It ranks fourth after maize, tef and sorghum both in area coverage and production [3].

Farmers in SSA seldom apply fertilizers in the recommended fertilizer rates at appropriate time that does not consider the crop nutrient requirement because of many socioeconomic constraints such as lack of supplies, cost of fertilizers, lack of access to financial credit, delivery delays, low and variable returns [12]. With rapid population growth, continuous and intensive cropping without restoration of the soil fertility, has depleted the nutrient base of most soils [2] resulting in poor crop yields. Nutrient depletion could be even worse in highly populated countries such as Ethiopia [8]. Hence, identification of proper fertilizer mix is beneficial at the macroeconomic level by improving the efficiency of fertilizer procurement and resource allocation.

Continuous cropping, high proportions of cereals in the cropping system, and the application of suboptimal levels 
of mineral fertilizers aggravate the decline in soil fertility [13]. Hence, identification of proper fertilizer mix is beneficial at the macroeconomic level by improving the efficiency of fertilizer procurement and resource allocation.

Therefore, profitable crop production requires adequate levels of phosphorus $(\mathrm{P})$ and other nutrients. For this careful planning is required because of volatile grain and fertilizer prices. So, sound soil test calibration is essential for successful fertilizer program and crop production. It is essential that the results of soil tests could be calibrated or correlated against crop responses from applications of plant nutrients in question as it is the ultimate measure of a fertilization program.

Phosphorus calibration is a means of establishing a relationship between a given soil test value and the yield response from adding nutrient to the soil as fertilizer. It provides information how much nutrient should be applied at a particular soil test value to optimize crop growth without excessive waste and confirm the validity of current $\mathrm{P}$ recommendations [4]. They enable to revise fertilizer recommendations for an area based on soil and crop type, $\mathrm{pH}$ and soil moisture content at time of planting. Soil tests are designed to help farmers predict the available nutrient status of their soils. Once the existing nutrient levels are established, producers can use the data to best manage what nutrients are applied, decide the application rate and make decisions concerning the profitability of their operations [7]. However, local assessments for the soil P critical levels and soil $\mathrm{P}$-requirement factors even for the major crops of the country are negligible [7].

Hence, calibration is a vital tool to attain the objective while calibrations are specific for each crop type and they may also differ by soil type, climate, and the crop variety. That means, fertilizer recommendations on soil test basis for economic crop production should be both location and situation specific and can be modified with changes in soil test value as well as input output ratios. Soil test based fertilizer recommendation plays a vital role in ensuring balanced nutrition to crops. Therefore, fertilizer application schedules should be based on the magnitude of crop response to applied nutrients at different soil fertility levels [13].

Currently, soil fertility research improvement is agreed with respect to site specific fertilizer recommendation in the country. However, as in all other regions of the country fertilizer recommendations in Yaya Gulele district is also not based on soil test results. Therefore, this study was initiated with the objectives to verify Soil test crop response based phosphorus recommendation on bread wheat conducted in Yaya Gulele district having different $P$ and $\mathrm{N}$ levels. The finding of soil test based crop response phosphorus calibration study was verified along with farmer practice and the control on farmers' holding. Partial budget analysis indicated that soil test based phosphorus-fertilizer recommendation is economically feasible for wheat production in the district. Fertilizer application based on soil test promotes increased efficient use of fertilizer for improving agricultural production.
Therefore, the objective of this study was:

1. To verify the feasibility of the Pc and Pf determined during site specific soil test based crop response fertilizer calibration

2. To create awareness on site specific fertilizer recommendation.

\section{Materials and Methods}

\subsection{Description of Study Area}

This verification experiment was conducted in Yaya Gulele district, 152 kilometers far from Finfine to North during the year 2018/19 cropping season. The geographical location of Yaya Gulele district ranges from $09^{\circ} 29^{\prime} 30^{\prime \prime}$ to $09^{\circ} 41^{\prime} 30^{\prime \prime} \mathrm{N}$ and $38^{\circ} 30^{\prime} 00^{\prime \prime}$ to $38^{\circ} 45^{\prime} 00^{\prime \prime} \mathrm{E}$. Annual rain fall of $1000 \mathrm{~mm}$ and the average temperature of $25^{\circ} \mathrm{C}$ and the soil are characterized by vertisol. Wheat is the dominant crop cultivated in the district.

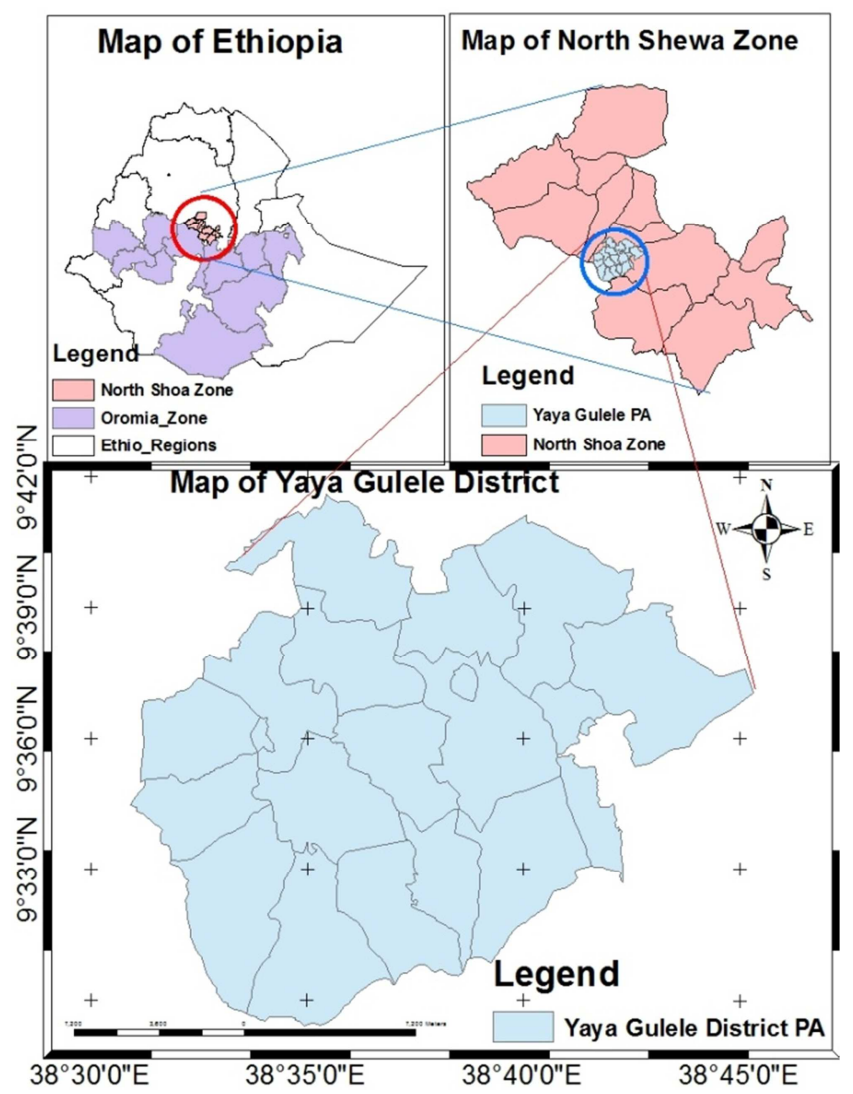

Figure 1. Location map of Yaya Gulele District.

\subsection{Experimental Procedures and Designs}

Prior to planting time, surface soil samples were collected from farmers' field from Yaya Gulele district following the standard procedures for available $\mathrm{P}$ analysis at a depth of $0-20 \mathrm{~cm}$. The collected samples were properly labeled, packed and transported to Fitche Agricultural Research Center's laboratory for analysis. A total of 37 composite soil samples were collected and 10 farmer's field having initial available phosphorus below P-critical 
concentration determined for the district were selected to

are listed in table 1.

conduct the experiment. The treatments of the experiments

Table 1. Treatments with their composition.

\begin{tabular}{ll}
\hline Control & No fertilizer application \\
\hline Blanket Recommendation & $100 \mathrm{~kg} / \mathrm{ha}$ DAP and $100 \mathrm{~kg} / \mathrm{ha} \mathrm{Urea}$ \\
STBFR (soil test based fertilizer Recommendation) & Optimum fertilizer Recommendation \\
\hline
\end{tabular}

Phosphorus fertilizer rate was calculated by using the formula given below.

Rate of P-to be applied $=(\mathrm{pc}-\mathrm{pi}) \times \mathrm{pf}$

Pc- Critical phosphorus concentration which was determined from the calibration study, $23 \mathrm{ppm}$

Pi- Initial available $\mathrm{P}$ that was derived from laboratory analysis from each farmer's field;
Pf- Phosphorus requirement factor which was derived from the calibration study 3.76 .

After having calculated the rate of $\mathrm{P}$ fertilizer in $\mathrm{kg}$ per hectare (Table 2), it was converted in to the experimental plot size. This helps to determine the amount of $\mathrm{P}$ fertilizer to be applied to each experimental farmer's field.

Table 2. P fertilizer values at each farmer's entire field of experiment.

\begin{tabular}{lllll}
\hline Farmers Name & Po (initial p-value) & Pc (critical p-concentration) & Pf (P-requirement factor) & Rate of fertilizer applied kg P/ha \\
\hline Farmer 1 & 14.69 & 23 & 3.76 & 31.25 \\
Farmer 2 & 11.12 & 23 & 3.76 & 44.67 \\
Farmer 3 & 18.79 & 23 & 3.76 & 15.83 \\
Farmer 4 & 5.91 & 23 & 3.76 & 64.26 \\
Farmer 5 & 2.93 & 23 & 3.76 & 75.46 \\
Farmer 6 & 12.47 & 23 & 3.76 & 39.59 \\
Farmer 7 & 4.39 & 23 & 3.76 & 69.97 \\
Farmer 8 & 9.48 & 23 & 3.76 & 50.84 \\
Farmer 9 & 3.63 & 23 & 3.76 & 72.83 \\
Farmer 10 & 4.1 & 23 & 3.76 & 71.06 \\
Mean & 8.75 & 3.76 & 53.58 \\
\hline
\end{tabular}

Source of fertilizer for $\mathrm{N}$ and $\mathrm{P}$ were Urea and DAP respectively. Improved variety of wheat known as danda'a was used as a test crop. The plot size was $10 \mathrm{~m} \times 10 \mathrm{~m}\left(100 \mathrm{~m}^{2}\right)$ for each treatments and $150 \mathrm{Kg} \mathrm{ha}^{-1}$ seed rate was used. All cultural practices for test crop including planting, harvesting, and protection against damage by disease and pests, weeding etc. were done according to farmer's practice in the area.

\subsection{Data Collection and Analysis}

During field experiment the agronomic data collected were: planting date, plant height, Stem length, Spike length, grain and biomass yield.

All agronomic data which were collected across locations were properly managed using EXCEL computer software and subjected to analysis of variance using $\mathrm{R}$ software program.

\subsection{Economic Analysis}

Marginal rate of return (MRR) was calculated both farmer practice and soil test based values by using the formula given blow.

$$
\operatorname{MRR}=\frac{\text { Net Income From Fertilized Field }- \text { Net Income From Unfertilized Field }}{\text { Total Variable Cost From Fertilizer Application }}
$$

Total variable cost is a cost incurred due to application of $\mathrm{P}$ fertilizer (both but in separate of Soil test based P calibration result and farmers' fertilizer rate) with the assumption that the rest of the costs incurred are the same for all treatments.

Gross income is obtained by multiplying mean grain yield $(\mathrm{kg} / \mathrm{ha})$ of each treatment by the price of one $\mathrm{kg}$ of the grain.

Net income is calculated by subtracting the total variable cost from the gross income. To use the marginal rate of return (MRR) as basis for fertilizer recommendation, the minimum acceptable rate of return (MARR) was set to $100 \%$.

\section{Results and Discussions}

\subsection{Soil Available Phosphorous}

The available $\mathrm{P}$ content of the soil was ranged from low to very high [9] with the value ranged from 3.63 to $18.79 \mathrm{ppm}$. Therefore, the soil of the study areas needs application of phosphorus containing fertilizers for crop production.

Table 3. Available soil phosphorous status before planting in Yaya Gulele district.

\begin{tabular}{ll}
\hline Site & Available P $(\mathbf{p p m})$ \\
\hline 1 & 14.69 \\
2 & 11.12 \\
3 & 18.79 \\
4 & 5.91 \\
5 & 2.93 \\
6 & 12.47 \\
7 & 4.39 \\
8 & 9.48 \\
9 & 3.63 \\
Average & 9.27 \\
\hline
\end{tabular}




\subsection{Grain yield of Wheat}

Wheat grain yield $(\mathrm{kg} / \mathrm{ha})$ was affected by different fertilizer rates as presented in table 1 below. According to Analysis of variance, the result of the experiment conducted in Yaya Gulele district indicated significant difference $(\mathrm{p}$ $<0.05$ ) among different fertilizer rates. The result of the study shows that wheat grain yield was highly increased with the application of $92 \mathrm{~N} \mathrm{Kg} / \mathrm{ha}$ and site specific fertilizer recommendation which gives $15.15 \mathrm{qt} / \mathrm{ha}$ yield advantage over the blanket type of fertilizer recommendation. The highest mean grain yield (37.13qt/ha) was recorded with the soil test based calibration result treatment which was significantly higher than the farmer practice (21.98 qt/ha). Gidane Tasew reported that, soil test crop response based fertilizer recommendation shows the higher yield as compared to blanket fertilizer recommendation [6]. The optimum $\mathrm{N}$ which is $92 \mathrm{Kg} / \mathrm{ha} \mathrm{N}$ and site specific fertilizer recommendation rate was influenced wheat grain yield with $68.94 \%$ grain yield advantage over the blanket type of fertilizer recommendation.

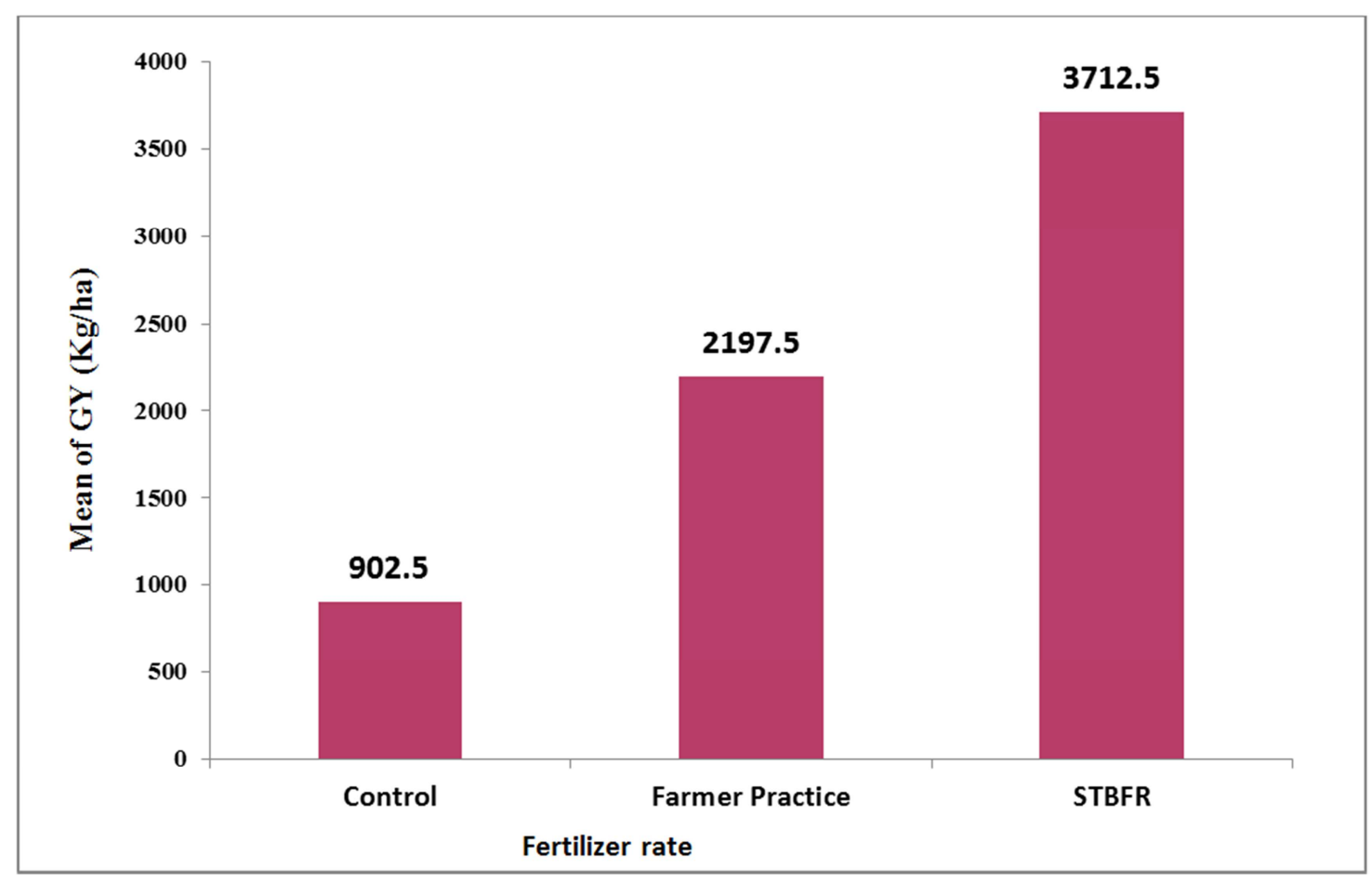

Figure 2. Wheat grain yield $(\mathrm{kg} / \mathrm{ha}$ ) as affected by different fertilizer rates recommendation.

Table 4. Effects of P-Fertilizer and supplemented nitrogen on some parameters of Bread Wheat.

\begin{tabular}{llllll}
\hline Treatment & PH $(\mathbf{c m})$ & St. L $(\mathbf{c m})$ & Sp. L $(\mathbf{c m})$ & TBM/ha $(\mathbf{k g})$ & GY $(\mathbf{k g} / \mathbf{h a})$ \\
\hline 1 & $66.2^{\mathrm{c}}$ & $56.304^{\mathrm{a}}$ & $4.87^{\mathrm{a}}$ & $2953.17^{\mathrm{b}}$ & $902.5^{\mathrm{a}}$ \\
2 & $80.9^{\mathrm{b}}$ & $84.402^{\mathrm{b}}$ & $7.52^{\mathrm{b}}$ & $5898.69^{\mathrm{a}}$ & $2197.5^{\mathrm{b}}$ \\
3 & $99.26^{\mathrm{a}}$ & $90.87^{\mathrm{c}}$ & $8.69^{\mathrm{c}}$ & $8145.16^{\mathrm{a}}$ & $3712.5^{\mathrm{c}}$ \\
LSD & 7.29 & 9.39 & 1.02 & 2631.43 & 624.31 \\
CV (\%) & 9.49 & 13 & 15.57 & 50.62 & 29.37 \\
\hline
\end{tabular}

$\mathrm{PH}=$ plant height, St. L=stem length, Sp. L=Spike length, GY=Grain Yield, LSD=Least Significant Difference, CV (\%)=Coefficient of Variation.

\subsection{Economical Analysis}

To estimate the economical significant of the different fertilizer rates, partial budget analysis (CIMMYT, 1988) was employed to calculate the Marginal rate of return (MRR) to investigate the economic feasibility of treatments. Based on actual unit prices during the year 2018/19 harvesting season (personal observation) farm gate price of 15ETB (Ethiopian Birr) per $\mathrm{kg}$ of wheat, $45 \mathrm{ETB}$ per qt. of biomass yield, $12.78 \& 10.4$ Birr per kg of DAP \& Urea, respectively (Table 1) were used to calculate variable cost.

Table 5. Partial Budget Analyses of Grain yield.

\begin{tabular}{|c|c|c|c|c|c|c|c|c|c|c|c|}
\hline \multirow[t]{2}{*}{ Trt } & \multirow[t]{2}{*}{ Fertilizer rate } & \multicolumn{2}{|c|}{$\begin{array}{l}\text { Variable Input } \\
\text { (Kg/ha) }\end{array}$} & \multicolumn{2}{|c|}{ Unit price (ETB) } & \multirow[t]{2}{*}{ TVC } & \multirow{2}{*}{$\begin{array}{l}\text { Output } \\
\text { (Kg/ha) }\end{array}$} & \multirow{2}{*}{$\begin{array}{l}\text { Unit price } \\
\text { (ETB) }\end{array}$} & \multirow{2}{*}{$\begin{array}{l}\text { Gross } \\
\text { Income }\end{array}$} & \multirow{2}{*}{$\begin{array}{l}\text { Net } \\
\text { Income }\end{array}$} & \multirow{2}{*}{$\begin{array}{l}\text { MRR } \\
(\%)\end{array}$} \\
\hline & & DAP & Urea & DAP & Urea & & & & & & \\
\hline 1 & Control & 0 & 0 & 12.78 & 10.4 & 0 & 902.5 & 15 & 13537.5 & 13538 & - \\
\hline 2 & Farmer practice & 100 & 100 & 12.78 & 10.4 & 2318 & 2197.5 & 15 & 32962.5 & 30645 & 738.01 \\
\hline 3 & Soil test based & 266.72 & 995.62 & 12.78 & 10.4 & 4403.13 & 3712.5 & 15 & 55687.5 & 51284 & 857.27 \\
\hline
\end{tabular}


The Marginal Rate of Return (MRR) were found to be $857.27 \%$ for soil test based fertilizer rate and $738.01 \%$ for farmer practice as indicated in Table 2. The economic analysis showed that the highest net income (51284 ETB) was obtained from soil test based recommended treatments with marginal rate of return $(857.27 \%)$ which is greater than the minimum rate of return (MRR) 100\% (CIMMT, 1998).

\section{Conclusion and Recommendation}

A field experiment was designed and studied to verify the determined optimum amount of nitrogen (92 kgN/ha), Prequirement factor (3.76) and the critical $\mathrm{P}$ concentration (23ppm) for Yaya Gulele districts.

An optimum nitrogen ( $92 \mathrm{Kg} \mathrm{N} / \mathrm{ha}$ ) rate and soil test based phosphorus fertilizer recommendation influence grain yield of bread wheat and accordingly, the maximum grain yield was $3713 \mathrm{~kg} / \mathrm{ha}$ with $68.94 \%$ of yield advantage over the blanket fertilizer recommendation. The economic analysis also showed that the highest net income (51284 ETB) was obtained from soil test based fertilizer recommended treatments with marginal rate of return $(857.27 \%)$ which is greater than the acceptable minimum rate of return $(100 \%)$.

Therefore, Demonstration and further popularization of the determined $\mathrm{Pc}$ and $\mathrm{Pf}$ before disseminating the recommendation should be the prerequisite.

\section{Acknowledgements}

First of all, we thank our God who enables us, in all down and ups, to perform our research activity properly. Secondly, the authors would like to thank Oromia Agricultural Research Institute for financial support and Fitche Agricultural Research Center for providing all the necessary facilities required for the research.

\section{References}

[1] Abeyo B, Braun H, Singh R, Ammar K, Payne T, et al. (2012) The performance of CIMMYT wheat germplasm in East Africa with special emphasis on Ethiopia. In: Book Abstracts of Wheat for Food security in Africa, Quilligan E, et al. In: (Eds.), conference AA, Ethiopia, pp: 22.
[2] Alice AS, Masateru M, Kengo I (2012). Effects of Soil Fertility Management on Growth, Yield, and Water-Use Efficiency of Maize (Zea mays L.) and Selected Soil Properties. Commun. Soil Sci. Plant Anal. 43 (6): 924-935.

[3] CSA (2018) Report on Area and Production of Major Crops (Private Peasant Holdings, Meher Season): Agricultural Sample Survey. $1^{\text {st }}$ (Vol.), Statistical bulletin 586, CSA, April 2018, Addis Ababa, Ethiopia.

[4] GetachewAgegnehu and Lakew, B. (2013). Soil test phosphorus calibration for malting barley (Hordeumvulgare L.) on Nitisols of central Ethiopian highlands. Tropical Agriculture 90, 177-187.

[5] GetachewAgegnehu, Nelson, P. N., Bird, M. I., and van Beek, C. (2015). Phosphorus Response and Fertilizer Recommendations for Wheat Grown on Nitisols in the Central Ethiopian Highlands. Communications in Soil Science and Plant Analysis 46, 2411-2424.

[6] Gidane Tasew. 2016. Verification and demonstration of soil test crop response based based phosphorus fertilizer recommendation rate on yield of teff in vertisol of Northern Ethiopia.

[7] Girma Chala. 2016. Soil test phosphorous calibration for potato production on Nitisols of central highlands Ethiopia. Ethiop. J. Sci. Sus. Dev. 120-137.

[8] Haileslassie A, Priess JA, Veldkamp E, Lesschen JP (2006). Smallholders' soil fertility management in the central highlands of Ethiopia: Implications for nutrient stocks, balances and sustainability of agroecosystems. Nutr. Cycl. Agroecosyst. 75: 135-146.

[9] Mehraban A (2013) The Effect of Different levels of Manure and Micro-nutrients on Yield and Some Physiological Properties of Spring Wheat. Technical J Engineering Appl Sci 3 (22): 3102-3106.

[10] Olsen, S. R. Cole, Watanable, F. S. and Dean, L. A. (1954) Estimation of available phosphorus in soils by extraction with sodium bicarbonate. Circ. U.S. Dep. Agric. 939.

[11] Partey ST, Thevathasan NV (2013). Agronomic Potentials of Rarely Used Agro-forestry Species for Smallholder Agriculture in Sub- Saharan Africa: An Exploratory Study. Commun. Soil Sci. Plant Anal. 44 (11): 1733-1748.

[12] Tanner, Tesfaye Tesemma and Takele Gebre. 2002. Optimizing fertilizer use in Ethiopia. 